\title{
PROPHYLAXIS OF SURGICAL SITE INFECTION WITH VANCOMYCIN IN 513 PATIENTS THAT UNDERWENT TO LUMBAR FUSION
}

\author{
PROFILAXIA DE INFECCÃO DE SÍTIO CIRÚRGICO COM VANCOMICINA EM 513 PACIENTES \\ SUBMETIDOS A FUSÃO DA COLUNA LOMBAR
}

\section{PROFILAXIS DE INFECCION DEL SITIO QUIRÚRGICO CON VANCOMICINA EN 513 PACIENTES COM ARTRODESIS LUMBARES}

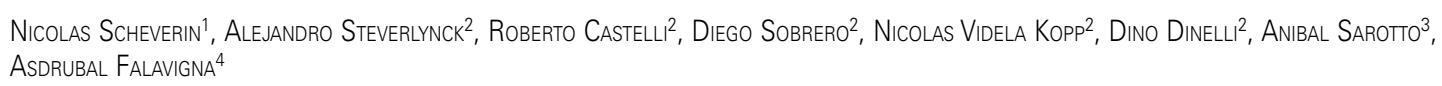

\begin{abstract}
Objective: To assess the prophylactic effects of local vancomycin on an infection of the surgical site in patients undergoing lumbar instrumented fusion. Methods: Retrospective study from January 2011 to June 2014 in patients with symptomatic and refractory lumbar spine stenosis and listhesis who underwent instrumented pedicle screw spinal fusion. Two groups of patient were analyzed, one using vancomycin on the surgical site, vancomycin group (VG) and the control group (CG) without topical vancomycin. The routine prophylactic procedures were performed in both groups: aseptic scrub technique, skin preparation, preoperative intravenous antibiotic therapy. The VG received a dose of $1 \mathrm{~g}$ of vancomycin mixed with the bone graft every three spinal levels fused and the group consisted of 232 patients. Results: 513 patients were analyzed, 232 in the VG and 281 in the CG. There was no statistical difference between the groups when the sex, mean surgery length, and mean bleeding volume were considered. The rate of infection for VG was reduced from $4.98 \%$ to $1.29 \%$ when compared with CG. Conclusion: The use of vancomycin added to the bone graft in posterior spinal fusion is associated with significantly lower rates of infection.
\end{abstract}

Keywords: Vancomycin; Spine/surgery; Infections; Spinal fusion.

\section{RESUMO}

Objetivo: Avaliar os efeitos profiláticos de vancomicina tópica na infecção do local cirúrgico em pacientes submetidos à fusão lombar instrumentada. Métodos: Estudo retrospectivo de janeiro de 2011 a junho de 2014 com pacientes com estenose sintomática e refratária da coluna lombar e listese que foram submetidos à fusão espinhal com parafuso pedicular. Dois grupos de pacientes foram analisados, em um dos quais se utilizou vancomicina no local cirúrgico: grupo vancomicina (GV) e um grupo controle (GC), sem vancomicina tópica. Os procedimentos profiláticos de rotina foram realizados para ambos os grupos: escovação asséptica das mãos, preparação da pele, terapia antibiótica intravenosa pré-operatória. O GV recebeu uma dose de $1 \mathrm{~g}$ de vancomicina misturada ao enxerto ósseo a cada três níveis espinais fundidos, e o grupo consistiu em 232 pacientes. Resultados: Foram analisados 513 pacientes, 232 no GV e 281 no GC. Não houve diferença estatística entre os grupos quando sexo, tempo médio de cirurgia e volume médio de sangramento foram considerados. A taxa de infecção para o GV foi reduzida de 4,98\% para 1,29\% quando comparado com o GC. Conclusão: O uso de vancomicina adicionada ao enxerto ósseo na fusão espinhal posterior é associado a taxas significantemente mais baixas de infecção.

Descritores: Vancomicina; Coluna vertebral/cirurgia; Infecção; Fusão vertebral.

\section{RESUMEN}

Objetivo: Evaluar los efectos profilácticos de la vancomicina local en el sitio quirúrgico en pacientes sometidos a cirugía instrumentada de columna lumbar. Métodos: Estudio retrospectivo desde enero 2011 hasta junio 2014 con pacientes con estenosis sintomática y refractaria al tratamiento y listesis intervenidos quirúrgicamente con tornillos pediculares y fusión posterior. Se analizaron dos grupos de pacientes, uno usando vancomicina en el sitio quirúrgico, grupo vancomicina (GV) y el grupo control (GC), sin vancomicina tópica. Los procedimientos de profilaxis de rutina se realizaron en ambos grupos: lavado antiséptico de manos, preparación del sitio quirúrgico, antibioticoterapia endovenosa prequirúrgica. El GV recibió $1 \mathrm{gr}$. de vancomicina mezclada con el injerto óseo cada 3 niveles espinales fusionados y dicho grupo consistió en 232 pacientes. Resultados: Se analizaron 513 pacientes, 232 en el GV y 281 en el GC. No hubo diferencias estadísticamente significativas entre ambos grupos en cuanto a sexo, tiempo quirúrgico y el volumen promedio de sangrado. La tasa de infección en el GV se redujo del 4,98 a 1,29 cuando se comparó con el GC. Conclusión: El uso de vancomicina agregada al injerto óseo en la fusión espinal posterior es asociado a una significativa disminución de las tasas de infección.

Descriptores: Vancomicina; Columna vertebral/cirugía; Infección; Fusión vertebral.

1. Hospital Municipal Dr. Diego E. Thompson, Department of Orthopedics, General San Martin, Argentina.

2. Hospital Militar Central, Department of Orthopedics, Capital Federal, Buenos Aires, Argentina.

3. Hospital Durand, Department of Orthopedics, Capital Federal, Buenos Aires, Argentina.

4. Universidade de Caxias do Sul, Department of Neurology, Laboratório de Estudos Clínicos e Modelos Básicos de Problemas de Coluna, Caxias do Sul, RS, Brazil. 


\section{INTRODUCTION}

Surgical site infections in spinal surgery with instrumentation are a complication that increases patient morbimortality and treatment costs due to prolonged hospitalization, multiple surgical procedures and the use of specific antibiotics. ${ }^{1,2}$ The rates of surgical site infection after spinal surgeries with decompression or fusion without instrumentation reported in the literature range from 0.7 to $2.3 \% .^{3-6}$ The use of instrumentation in spinal fusion increases the rates of postoperative infection from 0.3 to $20 \%$. $^{7-17}$

The most commonly isolated organism in surgical site infections is Staphylococcus aureus (SA) both methicillin-sensitive (MSSA) and methicillin-resistant (MRSA). The US National Health Safety Network informed that $30 \%$ of all reported procedures $(51 \%$ in neurological procedures, $49 \%$ in orthopedic surgery, and $33 \%$ in cardiovascular surgery) were caused by SA germs. 1,2,6,9,17

Surgeons must take a number of measures to try to control and reduce the risk of surgical site infections inherent either to the procedure (operative time, blood loss, use of instrumentation and revision surgeries) or to the patient (obesity, advanced age, malnutrition, smoking history, diabetes). $8,18,19$

The preventive strategies against postoperative spinal infections reported in the literature were intravenous antibiotic prophylaxis, 3,4,15,20-22 skin antisepsis. ${ }^{23}$ Chang et al. ${ }^{24}$ and Cheng et al. ${ }^{25}$ study mechanical methods prior to wound closure with detergent solutions or dilutions of Betadine, and Bhandari et al. ${ }^{26}$ also study low pressure irrigation with different solutions, Molinari et al. ${ }^{5}$ perform research on the effect of powdered antibiotics placed directly on the surgical site prior to closure. The aim of this study is to evaluate whether surgical site vancomycin mixed in bone grafts decreases infection rates in patients undergoing lumbosacral instrumented spine fusion.

\section{MATERIALS AND METHODS}

Retrospective study performed from January 2011 to June 2014. The study included consecutive symptomatic patients with radiological diagnosis of degenerative lumbar stenosis and listhesis who did not benefit from conservative treatment and had concordant clinical symptoms and radiological examinations. The institutional review board at our hospital has granted approval for this study. The surgical and study informed consent was read and discussed with the patient and their family.

The patients underwent a posterior midline approach to cauda equina and/or nerve root decompression and instrumented posterolateral fusions using titanium screws and local or iliac bone. Exclusion criteria were surgeries performed by anterior approach, pediatric surgery, surgery without instrumentation, thoracic or thoracolumbar spine surgery, use of interbody cage, oncologic or traumatic surgery, previous surgical site infections, known allergy to vancomycin, and patients who did not agree to participate in the study.

All patients were submitted to the preventive strategies to avoid surgical infection. Over a total of 784 lumbar surgeries were performed during this period; 513 met the inclusion criteria, 232 in the VG and 281 in the CG.

The same surgical team at a single institution performed all surgeries. The instruments were provided by a single vendor and were always sterilized using the same method.

The patient routine for surgery was to stop using non steroid drugs 10 days prior to surgery, the tetanus vaccine on the day, and preoperative shower with Pervinox soap on the day of surgery, Once the patient was admitted to the operating room antibiotic prophylaxis was done with cephalothin $2 \mathrm{~g} 30$ minutes pre-anesthesia, and as per nosocomial regulation and in accordance with the recommendations of the Argentine Society of Infectology. ${ }^{27}$ The skin of the surgical field was cleaned with chlorhexedine $2 \%$ soap solution. The surgeon's hands were scrubbed with chlorhexidine $2 \%$ and the surgical area prepared with Betadine Solution. Sterile surgical drapes and sterile Betadine dressings were placed over the surgical site. Postoperative antibiotic prophylaxis was performed with cephalotin
$1 \mathrm{~g}$ every 6 hours and for 48 hours. Drains were placed subfascially and left in place for 48 hours, except when a dural tear was observed with cerebrospinal fluid drainage despite the dural closure with suture or biological glue.

Intraoperative Vancomycin was indicated according to the surgeon's preference and beliefs. The Vancomycin group consisted of patients treated by one of the lead surgeons, while the control group were patients who had undergone surgery performed by the other lead surgeon. The patients who had intraoperative surgical site Vancomycin, were designated as the Vancomycin Group (VG), and the other patients were the Control Group (CG).

Vancomycin was chosen because it was reported to be effective against Gram-positive cocci and had better diffusion characteristics than other antibiotics. ${ }^{27-30}$ Winkler et al. ${ }^{29}$ and Buttaro et al.. ${ }^{30}$ had demonstrated that much significantly higher diffusion for Vancomycin was observed in an in vitro study where the local Vancomycin concentrations reached up to 20900 microg/L, much higher than Tobramycin, which only reaches 5700 microg/L. ${ }^{29,30}$

Vancomycin was used at a dose of $1 \mathrm{~g}$ every 3 levels of instrumentation. The antibiotic was mixed with bone graft and a small amount of the patient's own blood to promote adhesion of the antibiotics, 10 minutes before placing them in the posterolateral region of the lumbar spine. The levels of vancomycin were measured postoperatively in the VG at the drain and in the patient's blood during the immediate postoperative period and at 48 hours, to evaluate the systemic effect and the rate of absorption.

The diagnosis of wound infection was performed by germ isolation from the wound drainage liquid or from a wound collection in a postoperative patient with clinical and laboratory diagnosis of infection. Those patients underwent toilette and sequential cultures from surface to depth of the wound with multiple samples for pathogen isolation. Surgical site debridement of necrotic tissues was performed and the wound was irrigated with saline solution. After closure we left two deep drains, and began empirical antibiotic therapy as indicated by the Infectious Diseases Service. The diagnosis of surgical site infection was performed by positive cultures of the surgical wound after surgical toilette.

\section{Statistical Analysis}

Statistical analysis was performed using Fisher's exact test, t test, ANOVA, Mann and Winkler, and the STATA 13.1 program with an alpha error of 0.05 and a power of $95 \%$.

\section{RESULTS}

In this retrospective study 513 consecutive patients met the inclusion criteria where 232 patients received bone graft associated with vancomycin (VG) and 281 did not receive topic antibiotic (CG).

The analysis of the entire group showed a mean age of 54.96 . There was no statistical difference between the groups when the following variables were studied: sex (female $51.07 \%$ and male $48.92 \%)$, mean surgery length (112.89 minutes), and a mean bleeding volume $(412.29 \mathrm{ml})$. The mean hospitalization time was 4,138 days with no significant difference between the groups. The infected patients had their diagnosis performed after hospital discharge. The treatment days after the diagnosis of infection were not considered in this study. The mean follow up was 10 months (6-18 months). (Table 1)

The infection rate in the VG was $1.29 \%$ (3/232). Only one of the three cases was caused by MRSA infection, the 2 other patients had Klebsiella and Acynetobacter. On the contrary, a higher infection rate was observed in the CG, 4.98\% (14/281) and the most common germ isolated was SA, encountered in 7 cases (5 MSSA, and 2 MRSA), Escherichia Coli in 3 patients, Pseudomonas Aureaginosa in 2 patients, and Klebsiella and Enterobacter with 1 case each. There was a statistical decrease of infection in favor of the administration of vancomycin during surgery mixed with bone graft with $\mathrm{P}=0.0245$. (Table 2) 
Table 1. Demographic data and comparison of variables between vancomicyn Group and Control Group.

\begin{tabular}{|c|c|c|c|c|}
\hline & $\begin{array}{c}\text { Total } \\
\text { (N=513) }\end{array}$ & $\begin{array}{l}\text { Vancomycin group } \\
\text { (N=232) }\end{array}$ & $\begin{array}{l}\text { Control group } \\
(\mathrm{N}=281)\end{array}$ & $\mathbf{P}$ \\
\hline Age (Years) & 54.96 & $53(18-76)$ & 55 (18-78) & 0.0082 \\
\hline Female & 262 & $55 \%$ & $48 \%$ & 0.1112 \\
\hline $\begin{array}{l}\text { Obesity } \\
\text { (IMC >27) }\end{array}$ & $8.77 \%$ & $9.91 \%$ & $7.8 \%$ & 0.582 \\
\hline $\begin{array}{l}\text { Diabetes } \\
\text { mellitus }\end{array}$ & $7.01 \%$ & $6.8 \%$ & $7.7 \%$ & 0.8469 \\
\hline $\begin{array}{l}\text { Length of } \\
\text { surgery } \\
\text { (Minutes) }\end{array}$ & 112.89 & $\begin{array}{c}99.85 \\
(80-185)\end{array}$ & $\begin{array}{c}118.35 \\
(93-191)\end{array}$ & $<0.0001$ \\
\hline $\begin{array}{l}\text { Hospitalization } \\
\text { time (days) }\end{array}$ & 4.138 & $4.14(3-6)$ & $\begin{array}{l}4.13 \\
(3-7)\end{array}$ & 0.937 \\
\hline $\begin{array}{l}\text { Estimated } \\
\text { intraoperative } \\
\text { bleeding } \\
\text { volume } \\
\text { (mililiters) }\end{array}$ & 412.29 & $\begin{array}{c}390.21 \\
(200-950)\end{array}$ & $\begin{array}{c}420.88 \\
(260-950)\end{array}$ & 0.0008 \\
\hline \multicolumn{5}{|l|}{$\begin{array}{c}\text { Number of } \\
\text { cases by levels }\end{array}$} \\
\hline 2 levels & 263 & 130 & 133 & 0.837 \\
\hline 3 levels & 180 & 81 & 99 & 0.737 \\
\hline$>3$ levels & 70 & 21 & 49 & 0.523 \\
\hline Transfusions & 5 & $1.1 \%$ & $0.8 \%$ & 0.922 \\
\hline
\end{tabular}

Table 2. Comparison of infected patients by instrumented level between vancomicyn goup and control group.

\begin{tabular}{c|c|c}
\hline $\begin{array}{c}\text { Infected patients } \\
(\mathbf{n}=\mathbf{1 7})\end{array}$ & $\begin{array}{c}\text { Vancomycin group } \\
(\mathbf{n}=\mathbf{3})\end{array}$ & $\begin{array}{c}\text { Control group } \\
(\mathbf{n}=\mathbf{1 4})\end{array}$ \\
\hline 2 Levels surgery $(\mathbf{n}=\mathbf{2 6 3 )}$ & 0 & 4 \\
\hline 3 Levels surgery $(\mathbf{n}=\mathbf{1 8 0})$ & 2 & 6 \\
\hline >3 levels surgery $(\mathbf{n}=\mathbf{7 0})$ & 1 & 4 \\
\hline
\end{tabular}

The analysis of risk factors showed a significant difference between the CG and VG in age, length of surgery and intraoperative bleeding. A direct relation between age over 65 years and deep wound infection was observed in both $C G$ and VG, with an incidence of $57 \%$ and $66.66 \%$, respectively. No diabetic patient was present in the VG and 4 of 37 patients (10.81\%) had infection in the CG. Obese patients had an incidence of risk of infection of $28.57 \%$ in the CG and $33.33 \%$ in the VG. The association between infection and length of the surgery and blood loss was present in $35 \%$ of patients.

The analysis of vancomycin in the blood sample of the CG cases showed undetectable results in $86 \%$ of patients. In the rest of cases the maximum level detected was 2 micrograms $/ \mathrm{ml}$ on the first day postoperatively; after this period these values were undetectable. The measurement of vancomycin levels in the drainage fluid had a mean value of 997 micrograms/ml (191-1938) in the first 24hs and 67 micrograms/ml (11-157), 48 hours after surgery.

\section{DISCUSSION}

Surgical site infections after instrumented spinal surgeries are a devastating complication for the patient with an increase in costs caused by multiple surgeries, prolonged hospitalizations and the high cost of medication. The study presented showed that the use of vancomycin mixed with bone graft decreases surgical site infections after instrumented lumbar spine surgeries.
Despite a great number of strategies implemented before, during and after the surgical procedure in order to reduce the chances of infection after spinal surgery, the incidence mainly in instrumented fusion was high and ranged from 0.3 to $20 \% .^{4,9,12-15}$ Some risk factors inherent to the patient were reported, that cannot be modified, such as patient's age, ${ }^{31}$ and others factors that can be modified such as obesity, diabetes, urinary disorders, existing infections, malnutrition, abuse of alcohol and smoking. The surgical factors that increase the chance of infection were greater blood loss, increasing operating time, long instrumentation surgery and surgical technic with trauma of the soft tissue. ${ }^{20,31-36}$

The irrigation of the surgical site with crystalloid solutions and antiseptic solutions such as betadine dilutions and the removal of necrotic tissues has also been described as a strategy for reducing the bacterial inoculum and infection. ${ }^{3,37}$ Chang et al. ${ }^{24}$ and Cheng et al. ${ }^{25}$ reported that in all the cases in which irrigation of the surgical site was performed with dilutions of betadine none of them had infection. The critical review of those articles showed a low level of evidence in these studies. ${ }^{5}$

The reduction of surgical site infections after the use of powdered vancomycin prior to wound closure in instrumented spine surgery patients was observed by O'Neal et al. ${ }^{38}$ and Sweet et al.. ${ }^{39}$ The efficacy of vancomycin powder was confirmed by Molinari et al., ${ }^{5}$ who showed a decrease in infection rates from 1.14 to 0.33 , and by a meta-analysis published by Chiang et al.. ${ }^{40}$ The limitation of these studies was the lack of a control group.

The present study had a control group. Despite the non-randomization distribution of the patients in each group, the allocation of consecutive patients by surgeons' preference allowed a uniform number of patients in each group and equal distribution by year during the period of the study.

Vancomycin was the antibiotic chosen for surgical wound therapy because it was simple to use, had a low cost for the institution, had a very good diffusion and concentration compared to other antibiotics such as tobramycin ${ }^{29,30}$ reached high concentrations at the surgical site immediately, and was highly effective against the most common cause of surgical site infection germs such as Staphylococcus Sp. No systemic complications were reported using vancomycin, nor renal failure or nonunion complications in spinal surgeries. On the other hand, a recent in vitro study performed by Eder et al. ${ }^{41}$ showed that an increased dose of vancomycin caused a decrease in the migration capacity of osteoblasts, postulating the possible predisposition to pseudoartrosis. This phenomenon had no correlation with a cytotoxic effect on the osteoblasts. ${ }^{41}$ In the present study, the vancomycin concentration was determined in the drainage system and in the blood. The vancomycin levels in the drainage fluid were 3 times lower than the doses used by Eder et al.. ${ }^{41}$

The limitation of the study was the lack of randomization to vancomycin surgical wound therapy. Despite that, the consecutive inclusion of patients in the Vancomycin or Control group according to surgeon's preference and judgments from the same surgical team at a single institution is a valuable contribution.

The simple fact of mixing vancomycin with bone grafts before it is placed in the posterolateral portion of the lumbar spine infection reduces the rate of infection by 3.86 times when compared with the control group.

\section{CONCLUSIONS}

This retrospective study of 513 consecutive patients divided into two groups according to the use of $1 \mathrm{gr}$ of vancomycin mixed with the bone graft in instrumented lumbar spine surgeries showed an important decrease of infection rates (1.29\% versus $4.98 \%)$ at a mean follow-up of 10 months. Further investigation of this technique using randomization methodology with larger surgical subpopulations is necessary to confirm these results.

All authors declare no potential conflict of interest concerning this article. 


\section{REFERENCES}

1. Calderone RR, Garland DE, Capen DA, Oster H. Cost of medical care for postoperative spinal infections. Orthop Clin North Am. 1996;27(1):171-82.

2. de Lissovoy G, Fraeman K, Hutchins V, Murphy D, Song D, Vaughn BB. Surgical site infection: incidence and impact on hospital utilization and treatment costs. Am J Infect Control. 2009:37(5):387-97.

3. Haines SJ. Topical antibiotic prophylaxis in neurosurgery. Neurosurgery. 1982;11(2):250-3

4. Massie JB, Heller JG, Abitbol JJ, McPherson D, Garfin SR. Postoperative posterior spinal wound infections. Clin Orthop Relat Res. 1992;(284):99-108.

5. Molinari RW, Khera OA, Molinari WJ 3rd. Prophylactic intraoperative powdered vancomycin and postoperative deep spinal wound infection: 1,512 consecutive surgical cases over a 6-year period. Eur Spine J. 2012;21(Suppl 4):S476-82.

6. Weinstein MA, McCabe JP, Cammisa FP Jr. Postoperative spinal wound infection: a review of 2,391 consecutive index procedures. J Spinal Disord. 2000;13(5):422-6

7. Ayerza DI, Lanari F, Kenigsberg L, Gitard M, Valle A. La osteosíntesis transpedicular en el tratamiento de la espondilolistesis. Rev Asoc Argent Ortop Traumatol;58(2):128-40.

8. Blam OG, Vaccaro AR, Vanichkachorn JS, Albert TJ, Hilibrand AS, Minnich JM, Murphey SA. Risk factors for surgical site infection in the patient with spinal injury. Spine (Phila Pa 1976). 2003;28(13):1475-80.

9. Collins I, Wilson-MacDonald J, Chami G, Burgoyne W, Vineyakam P, Berendt T, et al. The diagnosis and management of infection following instrumented spinal fusion. Eur Spine J. 2008;17(3):445-50

10. Gelosi DJF, Furmento RA, Duran R. Estabilización de columna lumbosacra con tornillos pediculares. Evaluación de los primeros 185 casos ( Primera Parte). Rev Asoc Argent Ortop Traumatol. 1993;58(2):117-28.

11. Hodges SD, Humphreys SC, Eck JC, Covington LA, Kurzynske NG. Low postoperative infection rates with instrumented lumbar fusion. South Med J. 1998:91(12):1132-6.

12. Omeis IA, Dhir M, Sciubba DM, Gottfried ON, McGirt MJ, Attenello FJ, et al. Postoperative surgical site infections in patients undergoing spinal tumor surgery: incidence and risk factors. Spine (Phila Pa 1976). 2011;36(17):1410-9.

13. Pull ter Gunne AF, Cohen DB. Incidence, prevalence, and analysis of risk factors for surgical site infection following adult spinal surgery. Spine (Phila Pa 1976). 2009;34(13):1422-8.

14. Rechtine GR, Bono PL, Cahill D, Bolesta MJ, Chrin AM. Postoperative wound infection after instrumentation of thoracic and lumbar fractures. J Orthop Trauma. 2001:15(8):566-9.

15. Smith JS, Shaffrey Cl, Sansur CA, Berven SH, Fu KM, Broadstone PA, et al. Rates of infection after spine surgery based on 108,419 procedures: a report from the Scoliosis Research Society Morbidity and Mortality Committee. Spine (Phila Pa 1976). 2011:36(7):556-63

16. Steverlynck A, Castelli R, Sarotto A. Sistema de instrumentacion vertebral Coligne. Analisis y resultados. Rev Asoc Argent Ortop Tramatol. 2009;74(4):347-54.

17. Falavigna A, Righesso $O$, Teles AR, Kleber FD, Falavigna A. Righesso $O$, et al. Clinical and functional outcome of patients with deep wound infection after spinal lumbar fusion. Coluna/ Columna 2009;8(2):171-7.

18. Olsen MA, Mayfield J, Lauryssen C, Polish LB, Jones M, Vest J, Fraser VJ. Risk factors for surgical site infection in spinal surgery. J Neurosurg. 2003;98(Suppl 2):149-55

19. Klekamp J, Spengler DM, McNamara MJ, Haas DW. Risk factors associated with methicillin-resistant staphylococcal wound infection after spinal surgery. J Spinal Disord. 1999:12(3):187-91.

20. Gerometta A, Rodriguez Olaverri JC, Bitan F. Infections in spinal instrumentation. Int Orthop. 2012;36(2):457-64.

21. Ketonis C, Barr S, Shapiro IM, Parvizi J, Adams CS, Hickok NJ. Antibacterial activity of bone allografts: comparison of a new vancomycin-tethered allograft with allograft loaded with adsorbed vancomycin. Bone. 2011;48(3):631-8.
22. Sociedad Argentina de Infectologia. Guía para la profilaxis antibiótica prequirúrgica. Argentina; 2003

23. Savage JW, Anderson PA. An update on modifiable factors to reduce the risk of surgica site infections. Spine J. 2013;13(9):1017-29.

24. Chang FY, Chang MC, Wang ST, Yu WK, Liu CL, Chen TH. Can povidone-iodine solution be used safely in a spinal surgery? Eur Spine J. 2006;15(6):1005-14.

25. Cheng MT, Chang MC, Wang ST, Yu WK, Liu CL, Chen TH. Efficacy of dilute betadine solution irrigation in the prevention of postoperative infection of spinal surgery. Spine (Phila Pa 1976). 2005:30(15):1689-93.

26. Bhandari M, Adili A, Schemitsch EH. The efficacy of low-pressure lavage with different irrigating solutions to remove adherent bacteria from bone. J Bone Joint Surg Am. 2001;83-A(3):412-9.

27. Witsø E, Persen L, Løseth K, Bergh K. Adsorption and release of antibiotics from morselized cancellous bone. In vitro studies of 8 antibiotics. Acta Orthop Scand. 1999;70(3):298-304.

28. Witsø $E$, Persen $L$, Benum $P$, Bergh $K$. Release of netilmicin and vancomycin from cancellous bone. Acta Orthop Scand. 2002:73(2):199-205.

29. Winkler H, Janata O, Berger C, Wein W, Georgopoulos A. In vitro release of vancomycin and tobramycin from impregnated human and bovine bone grafts. J Antimicrob Chemother. 2000:46(3):423-8

30. Buttaro MA, Gimenez MI, Greco G, Barcan L, Piccaluga F. High active local levels of vancomycin without nephrotoxicity released from impacted bone allografts in 20 revision hip arthroplasties. Acta Orthop. 2005;76(3):336-40.

31. Cahill PJ, Warnick DE, Lee MJ, Gaughan J, Vogel LE, Hammerberg KW, Sturm PF. Infection after spinal fusion for pediatric spinal deformity: thirty years of experience at a single institution. Spine (Phila Pa 1976). 2010;35(12):1211-7.

32. Fang $A$, Hu SS, Endres $N$, Bradford DS. Risk factors for infection after spinal surgery. Spine (Phila Pa 1976). 2005;30(12):1460-5.

33. Wimmer C, Gluch H, Franzreb M, Ogon M. Predisposing factors for infection in spine surgery: a survey of 850 spinal procedures. J Spinal Disord. 1998:11(2):124-8.

34. Perry JW, Montgomerie JZ, Swank S, Gilmore DS, Maeder K. Wound infections following spinal fusion with posterior segmental spinal instrumentation. Clin Infect Dis. 1997;24(4):558-61.

35. Thalgott JS, Cotler HB, Sasso RC, LaRocca H, Gardner V. Postoperative infections in spinal implants. Classification and analysis-a multicenter study. Spine (Phila Pa 1976). $1991 ; 16(8): 981-4$.

36. Abbey DM, Turner DM, Warson JS, Wirt TC, Scalley RD. Treatment of postoperative wound infections following spinal fusion with instrumentation. J Spinal Disord. 1995;8(4):278-83

37. Lonstein J, Winter R, Moe J, Gaines D. Wound infection with Harrington instrumentation and spine fusion for scoliosis. Clin Orthop Relat Res. 1973:(96):222-33

38. O'Neill KR, Smith JG, Abtahi AM, Archer KR, Spengler DM, McGirt MJ, et al. Reduced surgical site infections in patients undergoing posterior spinal stabilization of traumatic injuries using vancomycin powder. Spine J. 2011:11(7):641-6.

39. Sweet FA, Roh M, Sliva C. Intrawound application of vancomycin for prophylaxis in instrumented thoracolumbar fusions: efficacy, drug levels, and patient outcomes. Spine (Phila Pa 1976). 2011:36(24):2084-8

40. Chiang HY, Herwaldt LA, Blevins AE, Cho E, Schweizer ML. Effectiveness of local vancomycin powder to decrease surgical site infections: a meta-analysis. Spine J. 2014;14(3):397-407.

41. Eder C, Schenk S, Trifinopoulos J, Külekci B, Kienzl M, Schildböck S, Ogon M. Does intrawound application of vancomycin influence bone healing in spinal surgery? Spine J 2014 14:S2-3. doi 10.1016/j.spinee.2014.08.018 